\title{
Morphological Parameters and their Implications in Forest Watershed
}

\author{
K.C. Patel ${ }^{1}$, N.K. Gontia ${ }^{2}$ and K.M. Gojiya ${ }^{3}$ \\ ${ }^{1}$ Department of Soil and Water Conservation Engineering, ${ }^{3}$ Department of Soil and Water \\ Conservation Engineering, ${ }^{2}$ College of Agricultural Engineering and Technology, Junagadh \\ Agricultural University, Junagadh, Gujarat, 362001, India \\ *Corresponding author
}

\section{Keywords \\ Watershed, Morphology, Forest, Remote Sensing and GIS \\ Article Info \\ Accepted: \\ 20 March 2019 \\ Available Online: \\ 10 April 2019}

\section{A B S T R A C T}

Morphometric analysis, which refers to the science of quantitative analysis of land surface, has been carried on Kamleshwar watershed of Hiran River in Gujarat using remote sensing and GIS techniques. Digital Elevation Model of $30 \mathrm{~m} \times 30 \mathrm{~m}$ resolution was used to prepare the detailed drainage map in ArcGIS software and stream ordering was in which study area has trunk order of 5. Total seventeen morphometric parameters including linear, areal and relief aspects have been estimated. Mean bifurcation ratio of the watershed has been calculated to be 3.84 which indicates slightly dissected drainage basin. Low drainage density of $2.18 \mathrm{~km} / \mathrm{km}^{2}$ very well explains high infiltration in soil and less runoff due to dense forest cover. Drainage texture of $4.08 \mathrm{~km}^{-1}$ is coarse to moderate leading to reduce soil erosion. Form factor ratio and elongation ratio are 0.35 and 0.67 respectively which favours in lower peaks of longer duration with elongated watershed, which is good for avoiding the floods in downstream. Relatively low relief ratio of 0.016 translates low intensity of erosion processes. Low drainage density and relief results in moderately low ruggedness number of 0.52 . The study shows potential usefulness of GIS techniques in determining geomorphological landforms of forest watersheds which can be useful in various hydrologic modelling studies.

\section{Introduction}

Morphological analysis is the measurement and mathematical analysis of the configuration of the earth's surface, shape and dimension of its landforms. The quantitative analysis of morphometric parameters is found to be of immense utility in river basin evaluation, watershed prioritization for soil and water conservation and natural resources management at watershed level. The morphological analysis is important in any hydrological study such as assessment of groundwater potential, groundwater management, pedology and environmental assessment (Sreedevi et al., 2009). Hydrologists and geomorphologists have established that certain relations are most important between runoff characteristics, and geographic and geomorphic characteristics of drainage basin systems. Various important hydrologic phenomena can be correlated with 
the physiographic characteristics of drainage basins such as size, shape, slope of drainage area, drainage density, size and length of the contributories etc. Remote sensing techniques using satellite images and aerial photographs are convenient tools for morphometric analysis. The satellite remote sensing has the ability to provide synoptic view of large area and is very useful in analysing drainage morphometry (Chopra et al., 2005). Jasani and Mansuriya (2011) worked on geomorphological studies of Meghal river basin using Remote Sensing and GIS. In the study, linear parameters like bifurcation ratio, drainage frequency, length of overland flow, drainage density and shape parameters like elongation ratio, form factor, circularity ratio and compactness coefficient were estimated. Mishra et al., (2011) analysed the morphometric characteristics of Tons basin, Madhya Pradesh, based on watershed approach. The stream numbers, orders, lengths and other morphometric parameters like bifurcation ratio, drainage density, stream frequency, shape parameters etc. were measured. In many studies, morphometric analysis has been used for the prioritization of watersheds (Sethupathi et al., 2011; Singh and Singh, 2011). Saeedrashed and Guven (2013) studied the geomorphological parameters of the Lower Zab watershed based on a more precise DEM method alternative to the conventional digitized map method. They concluded that the geomorphological parameters of the Lower Zab watershed derived by GIS-based DEM could be practically used in many hydrologic modelling studies such as generating synthetic unit hydrograph or flood routing researches as well.

\section{Materials and Methods}

\section{Study area}

This study was conducted on Hiran-1 river watershed located in Gir Sanctuary, Gujarat,
India. Catchment area falls between $21^{\circ} 7^{\prime} \mathrm{N}$ to $21^{\circ} 14^{\prime} \mathrm{N}$ latitudes and $70^{\circ} 39^{\prime} \mathrm{E}$ to $70^{\circ}$ 46' E longitudes (Fig. 1). Area receives annual average rainfall of $1080 \mathrm{~mm}$.

The stream ordering was done using Strahler and Chow (1964) technique. The methodology adopted to determine the different morphometric parameters are as described in Table 1. The drainage map was prepared in GIS software ArcMap 10.3 using Digital Elevation Model (DEM) of $30 \times 30 \mathrm{~m}$ resolution obtained from Bhuvan portal of NRSC/ISRO, which was originally generated using Indian Remote Sensing Satellite Cartosat-1 imagery. The prepared drainage map of the basin was used in the ArcMap to prepare the stream order map. The stream ordering can be done in ArcMap using Stream Order function of Spatial Analyst Hydrology tool. The stream ordering was done manually using the Editor tool of ArcMap. Each stream segment was edited and stream order was given in attributes table simultaneously. The various tools like clip and merge were used to change the direction of flow and to join the stream segment, respectively. Prepared stream order map of the study area is shown in Figure 2. The stream order map was used for further morphological analysis including manually counting the number of streams in each stream order and measuring the length of various streams for further use in analysis. Different morphometric parameters estimated for the study area including linear, areal and relief aspects are described in the Table 1 .

\section{Results and Discussion}

\section{Linear aspects}

Prepared stream order map of the study area is shown in Figure 2. Numbers of streams were calculated manually from the prepared map. The study area of Hiran-1 River watershed was fifth order basin. For the first, second, third, fourth and fifth order streams, 
numbers of streams were 203, 44, 10, 3 and 1 respectively. According to Horton (1945), the numbers of stream segments of each order form an inverse geometric sequence with order number. In the study, stream number $\mathrm{Nu}$ supported Horton's law. Study area basin perimeter $(\mathrm{P})$ and maximum basin length $\left(\mathrm{L}_{\mathrm{b}}\right)$ were found to be $64.04 \mathrm{~km}$ and $14.92 \mathrm{~km}$ respectively.

As order increased, numbers of streams were found to be decreasing; contrary to that, the mean stream lengths were increased with the increase in order. In the study, stream length decreases with increasing stream order, which supports Horton's law. Mean stream lengths were calculated by dividing the total length of all streams in a particular order by the number of streams in that order. Mean stream length of first, second, third, fourth and fifth order were $0.42 \mathrm{~km}, 0.98 \mathrm{~km}, 2.65 \mathrm{~km}, 3.63 \mathrm{~km}$ and $4.19 \mathrm{~km}$ respectively. The bifurcation ratio is dimensionless property and generally ranges from 3.0 to 5.0. The lower values of bifurcation ratio are characteristics of the watersheds, which have suffered less structural disturbances (Strahler, 1964) and the drainage pattern has not been distorted because of the structural disturbances. Bifurcation ration in study area ranges from 3 to 4.61. Mean bifurcation ratio of the watershed was found to be relatively low of 3.84, which indicates that watershed is not affected by structural disturbances. Table 2 shows the stream order, number of streams, mean stream length, stream length ratio and bifurcation ration for the respective stream orders.

\section{Areal aspects}

The areal aspect is the two dimensional properties of a basin. In areal aspects, basin area $(A)$, drainage density $\left(D_{d}\right)$, drainage texture $\left(D_{t}\right)$, form factor ratio $\left(R_{f}\right)$, elongation ratio $\left(R_{e}\right)$, circularity ratio $\left(R_{c}\right)$, constant of channel maintenance $(C)$ and length of overland flow $\left(L_{g}\right)$ were determined. The Hiran-1 catchment area found as $7819 \mathrm{~km}^{2}$. All the morphometric parameters of areal aspects for the study area are shown in Table 3.

Drainage density has long been recognized as topographic characteristic of fundamental significance. Drainage basin with high drainage density indicates that a large proportion of the precipitation runs off, on the other hand a low drainage density indicates the most rainfall infiltrates the ground and few channels are required to carry the runoff (Nag, 1998). Drainage density of the study area was found to be moderate around 2.18 $\mathrm{km} / \mathrm{km}^{2}$, which suggests that study area has moderate permeable sub-soil and thick vegetative cover.

Drainage texture is the total number of stream segments of all order in a basin per perimeter of the basin (Horton, 1945). It is important to geomorphology which means that the relative spacing of drainage lines. Smith (1950) has classified drainage texture into 5 different textures i.e., very coarse $(<2)$, coarse $(2$ to 4$)$, moderate (4 to 6 ), fine (6 to 8 ) and very fine $(>8)$. More is the texture more will be dissection and leads more erosion. The study area drainage texture was calculated $4.08 \mathrm{~km}^{-1}$ and falls under moderate drainage texture category.

Three parameters viz. elongation ratio, circulatory ratio and form factor are used for characterizing drainage basin shape, which is an important parameter from hydrological point of view. As Strahler (1964), elongation ratio $<0.7$ is considered to be elongated, 0.8 0.7 is less elongated, $0.9-0.8$ as oval and $>0.9$ to be circular. Elongation ratio of the Hiran-1 River watershed was found to be 0.67 , which indicates that the watershed is elongated. Miller (1953) has defined the circularity ratio 
as the ratio of the area of the basin to the area of the circle having same circumference as the basin perimeter. The value of circularity ratio of the study area is 0.24 . According to Horton (1932), form factor may be defined as the ratio of basin area to square of the basin length. The value of form factor would always be less than 0.754 for a perfectly circular watershed. Smaller the value of form factor, more elongated will be the basin. The study area form factor ratio is 0.35 which favors lower peaks of longer duration.

The term length of overland flow is used to describe the length of flow of water over the ground before it becomes concentrated in definite stream channels. Length of overland flow of Hiran-1 River basin was $0.23 \mathrm{~km}$ which shows low surface runoff of the study area. Constant of Channel Maintenance indicates the requirement of units of watershed surface to bear one unit of channel length. Constant of Channel Maintenance of the study area was found to be $0.46 \mathrm{~km}$. The drainage basin having higher values of this parameter reveals a surface of high permeability.

\section{Relief aspects}

Linear and areal features have been considered as the two dimensional aspect lie on a plan. The third dimension introduces the concept of relief. Maximum $(Z)$ and minimum (z) elevations of the Hiran-1 River basin are $418 \mathrm{~m}$ and $182 \mathrm{~m}$ from mean sea level respectively. Basin relief $(H)$, relief ratio $\left(R_{r}\right)$, channel gradient $\left(C_{g}\right)$ and ruggedness number $\left(R_{n}\right)$ are the relief aspects of the basin which are calculated under morphometric analysis. Table 4 shows all the relief aspect parameters of the morphometric analysis for Hiran-1 River watershed.

Table.1 Morphometric parameters with formulae

\begin{tabular}{|c|c|c|}
\hline Parameter & Formula & Reference \\
\hline \multicolumn{3}{|c|}{ Linear aspects } \\
\hline Stream Order $\left(S_{\mu}\right)$ & Hierarchical rank & Strahler and Chow (1964) \\
\hline Bifurcation Ratio $\left(R_{\mathrm{b}}\right)$ & $\begin{array}{l}R_{b}=N_{\mu} / N_{\mu}+1 \\
\text { Where, } R_{b}=\text { Bifurcation ratio, } \\
N_{\mu}=\text { No. of stream segments of a given order, } \\
N_{\mu}+1=\text { No. of stream segments of next higher } \\
\text { order. }\end{array}$ & Schumn (1956) \\
\hline Stream Length $\left(L_{\mu}\right)$ & Length of the stream $(\mathrm{km})$ & Horton (1945) \\
\hline $\begin{array}{l}\text { Stream Length Ratio } \\
\left(R_{L}\right)\end{array}$ & $\begin{array}{l}R_{L}=L_{s m} / L_{a m}-1 \\
\text { Where, } L_{s m}=\text { Mean stream length of a given } \\
\text { order, } \\
L_{g m}-1=\text { Mean stream length of next lower } \\
\text { order }\end{array}$ & Horton (1945) \\
\hline $\begin{array}{l}\text { Length of Overland } \\
\text { Flow }\left(L_{g}\right)\end{array}$ & $\begin{array}{l}L_{g}=1 / 2 D \\
\text { Where, } D=\text { Drainage density }\left(\mathrm{km} / \mathrm{km}^{2}\right)\end{array}$ & Horton (1945) \\
\hline Basin Perimeter $(P)$ & $\begin{array}{l}P=\text { Outer boundary of drainage basin } \\
\text { measured in kilometres. }\end{array}$ & Schumn (1956) \\
\hline
\end{tabular}




\begin{tabular}{|c|c|c|}
\hline Basin Length $\left(L_{b}\right)$ & $L_{b}=1.312 \times A^{0.568}$ & Schumn (1956) \\
\hline \multicolumn{3}{|c|}{ Areal aspects } \\
\hline Basin Area $(A)$ & $\begin{array}{l}\text { Area from which water drains to a common } \\
\text { stream and boundary determined by opposite } \\
\text { ridges. }\end{array}$ & Strahler and Chow (1964) \\
\hline Drainage Density $\left(D_{\frac{d}{d}}\right)$ & $\begin{array}{l}D_{\alpha}=L_{\mu} / A \\
\text { Where, } D_{\alpha}=\text { Drainage density }\left(\mathrm{km} / \mathrm{km}^{2}\right), \\
L_{\mu=}=\text { Total stream length of all orders and } \\
A=\text { Area of the basin }\left(\mathrm{km}^{2}\right) .\end{array}$ & Horton (1932) \\
\hline Drainage Texture $\left(D_{t}\right)$ & $\begin{array}{l}D_{t}=N_{\mu} / P \\
\text { Where, } N_{\mu}=\text { No. of streams in a given order and } \\
P=\text { Perimeter }(\mathrm{km})\end{array}$ & Horton (1945) \\
\hline Form Factor Ratio $\left(R_{f}\right)$ & $\begin{array}{l}R_{f}=A / L_{b}^{2} \\
\text { Where, } A=\text { Area of the basin and } \\
L_{b}=\text { (Maximum) basin length }\end{array}$ & Horton (1932) \\
\hline Elongation Ratio $\left(R_{\varepsilon}\right)$ & $\begin{array}{l}R_{e}=(2(\sqrt{(A / \pi)})) / L_{b} \\
\text { Where, } A=\text { Area of the basin }\left(\mathrm{km}^{2}\right) \\
L_{b}=(\text { Maximum }) \text { Basin length }(\mathrm{km})\end{array}$ & Schumn (1956) \\
\hline Circularity Ratio $\left(R_{\varepsilon}\right)$ & $\begin{array}{l}R_{0}=4 \pi A / P^{2} \\
\text { Where, } A=\text { Basin area }\left(\mathrm{km}^{2}\right) \text { and } \\
P=\text { Perimeter of the basin }(\mathrm{km})\end{array}$ & Miller(1953) \\
\hline $\begin{array}{l}\text { Constant of Channel } \\
\text { Maintenance }(C)\end{array}$ & $\begin{array}{l}C=1 / D_{d} \\
\text { Where, } D_{d}=\text { Drainage density }\left(\mathrm{km} / \mathrm{km}^{2}\right)\end{array}$ & Schumn (1956) \\
\hline \multicolumn{3}{|c|}{ Relief aspects } \\
\hline Basin Relief $(H)$ & $\begin{array}{l}H=Z-z \\
\text { Where, } Z=\text { Maximum elevation of the basin } \\
\text { (m) and } z=\text { Minimum elevation of the basin (m) }\end{array}$ & $\begin{array}{l}\text { Schumn } \\
\text { (1956) }\end{array}$ \\
\hline Relief Ratio $\left(R_{r}\right)$ & $\begin{array}{l}R_{r}=H / L_{b} \\
\text { Where, } H=\text { basin relief }(\mathrm{m}) \text { and } \\
L_{b}=\text { Basin length }(\mathrm{m})\end{array}$ & $\begin{array}{l}\text { Schumn } \\
\text { (1956) }\end{array}$ \\
\hline Channel Gradient $\left(C_{g}\right)$ & $\begin{array}{l}C_{g}=H /\left((\pi / 2) \times C_{l p}\right) \\
\text { Where, } H=\text { basin relief }(\mathrm{m}) \text { and } \\
C_{l p}=\text { Longest Dimension Parallel to the Principal } \\
\text { Drainage Line }(\mathrm{km})=L_{b}\end{array}$ & Bulkley (1975) \\
\hline $\begin{array}{l}\text { Ruggedness number } \\
\left(R_{n}\right)\end{array}$ & $\begin{array}{l}R_{n}=H \times D_{d} \\
\text { Where } H=\text { basin relief }(\mathrm{m}) \text { and } \\
D_{\mathrm{d}}=\text { Drainage density }\left(\mathrm{km} / \mathrm{km}^{2}\right)\end{array}$ & Strahler (1968) \\
\hline
\end{tabular}


Table.2 Linear aspect morphometric parameters

\begin{tabular}{|c|c|c|c|c|c|c|}
\hline $\begin{array}{c}\text { Stream } \\
\text { Order } \\
\left(\boldsymbol{S}_{\boldsymbol{\mu}}\right)\end{array}$ & $\begin{array}{c}\text { Number } \\
\text { of } \\
\text { Streams } \\
\left(\boldsymbol{N}_{\boldsymbol{\mu}}\right)\end{array}$ & $\begin{array}{c}\text { Total } \\
\text { Stream } \\
\mathbf{L e n g t h} \\
\left(\boldsymbol{L}_{\boldsymbol{\mu}}\right), \mathbf{k m}\end{array}$ & $\begin{array}{c}\text { Mean } \\
\text { stream } \\
\text { length, } \\
\mathbf{k m}\end{array}$ & $\begin{array}{c}\text { Bifurcatio } \\
\mathbf{n} \text { ratio } \\
\left(\boldsymbol{R}_{\boldsymbol{b}}\right)\end{array}$ & $\begin{array}{c}\text { Mean } \\
\text { of } \boldsymbol{R}_{\boldsymbol{b}}\end{array}$ & $\begin{array}{c}\text { Stream } \\
\text { length } \\
\text { ratio }\left(\boldsymbol{R}_{\boldsymbol{L}}\right)\end{array}$ \\
\hline $\mathbf{1}$ & 203 & 85.55 & 0.42 & 4.61 & 3.84 & - \\
\hline $\mathbf{2}$ & 44 & 43.53 & 0.98 & 4.4 & & 2.35 \\
\hline $\mathbf{3}$ & 10 & 26.50 & 2.65 & 3.33 & & 2.68 \\
\hline $\mathbf{4}$ & 3 & 10.88 & 3.63 & 3 & & 1.37 \\
\hline $\mathbf{5}$ & 1 & 4.19 & 4.19 & - & & 1.16 \\
\hline
\end{tabular}

Table.3 Areal aspect morphometric parameters

\begin{tabular}{|l|l|}
\hline Parameter & Value \\
\hline Basin Area $(A)$ & $78.19 \mathrm{~km}^{2}$ \\
\hline Drainage Density $\left(D_{d}\right)$ & $2.18 \mathrm{~km} / \mathrm{km}^{2}$ \\
\hline Drainage Texture $\left(D_{t}\right)$ & $4.08 \mathrm{~km}^{-1}$ \\
\hline Form Factor Ratio $\left(R_{f}\right)$ & 0.35 \\
\hline Elongation Ratio $\left(R_{\varepsilon}\right)$ & 0.67 \\
\hline Circularity Ratio $\left(R_{e}\right)$ & 0.24 \\
\hline Constant of Channel Maintenance $(C)$ & $0.46 \mathrm{~km}$ \\
\hline Length of Overland Flow $\left(L_{g}\right)$ & $0.23 \mathrm{~km}$ \\
\hline
\end{tabular}

Table.4 Relief aspect morphometric parameters

\begin{tabular}{|l|l|}
\hline Parameter & Value \\
\hline Maximum elevation of the basin $(Z)$ & $418 \mathrm{~m}$ \\
\hline Minimum elevation of the basin $(z)$ & $182 \mathrm{~m}$ \\
\hline Basin Relief $(H)$ & $236 \mathrm{~m}$ \\
\hline Relief Ratio $\left(R_{r}\right)$ & 0.0158 \\
\hline Channel Gradient $\left(C_{g}\right)$ & $10.07 \mathrm{~m} / \mathrm{km}$ \\
\hline Ruggedness number $\left(R_{n}\right)$ & 0.515 \\
\hline
\end{tabular}


Fig.1 Study area location

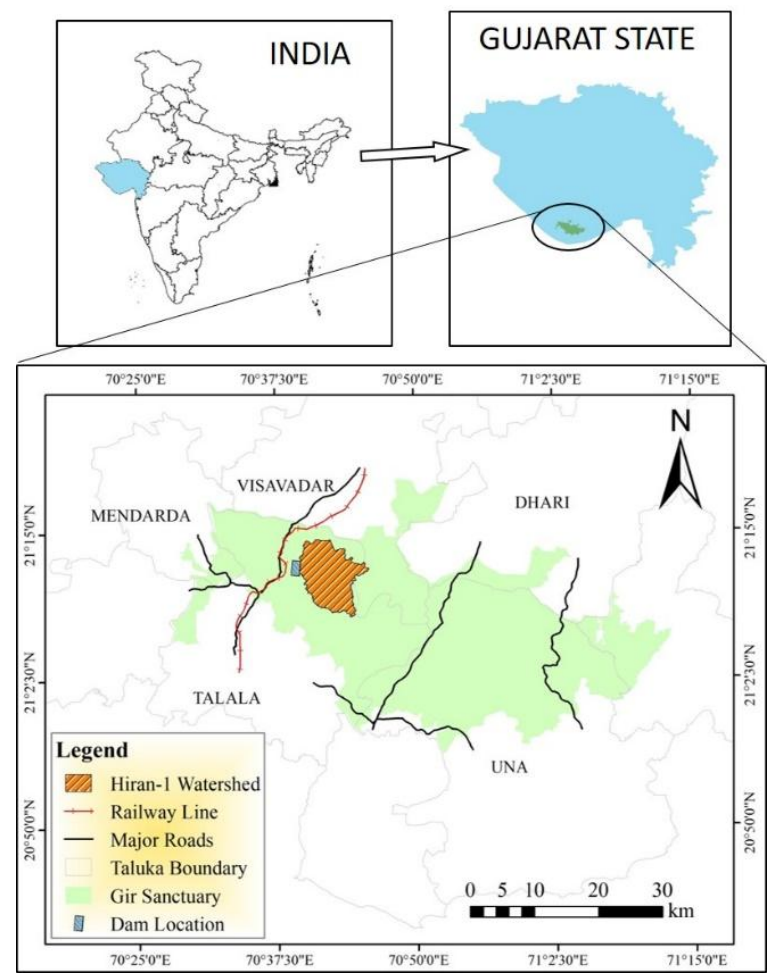

Fig.2 Stream order map of Hiran-1 River watershed

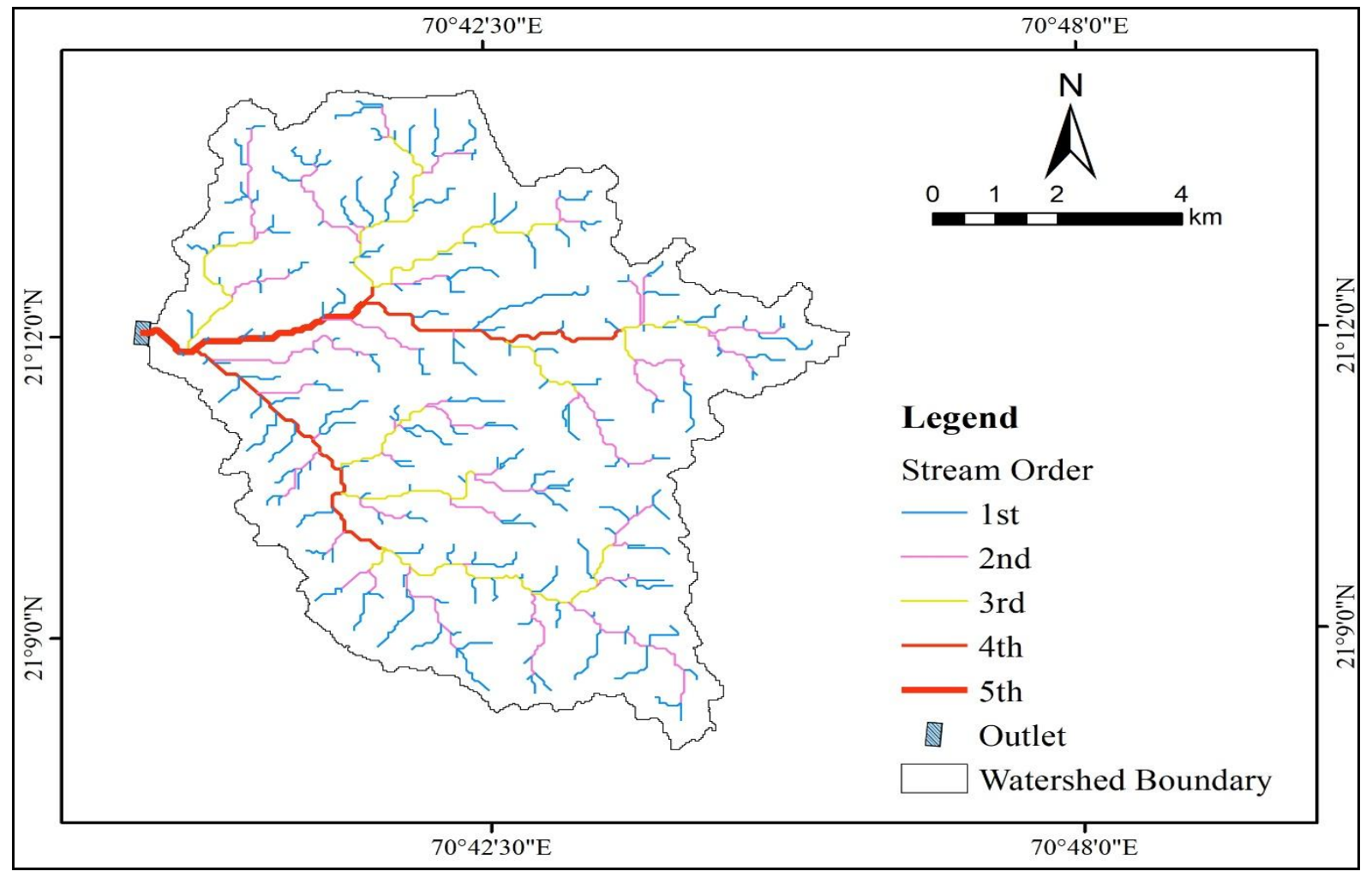


Basin relief is the elevation difference of the highest and lowest point of the basin. Basin relief of the study area was found $236 \mathrm{~m}$. Relief ratio is defined as the ratio between the total relief of a basin i.e. elevation difference of lowest and highest points of a basin, and the longest dimension of the basin parallel to the principal drainage line (Schumn, 1956). Relief ratio is an indicator of intensity of erosion processes operating on the slope of the basin. Relief ratio of the current study was found to be relatively low about 0.016 . Channel gradient is the grade measured by the ratio of drop in elevation of a stream per unit horizontal distance (Bulkley, 1975), usually expressed as meters per kilometer. Channel gradient of the study area was $10.07 \mathrm{~m} / \mathrm{km}$. Strahler (1968) describes ruggedness number as the product of basin relief and drainage density. Extremely high values of ruggedness number occur when slopes of the basin are not only steeper but long, as well. Study area ruggedness number was moderately low around 0.52 which implies that area is less prone to soil erosion.

Morphometric analysis forHiran-1 river watershed located in Gir Sanctuary was done on three aspects; linear, areal and relief aspects. Stream order $\left(S_{\mu}\right)$, number of streams in particular order $\left(N_{\mu}\right)$, total stream length $\left(L_{\mu}\right)$, mean stream length, bifurcation ratio $\left(R_{b}\right)$ and stream length ratio $\left(R_{L}\right)$ were estimated under linear aspects. In areal aspects, basin area $(A)$, drainage density $\left(D_{d}\right)$, drainage texture $\left(D_{t}\right)$, form factor ratio $\left(R_{f}\right)$, elongation ratio $\left(R_{e}\right)$, circularity ratio $\left(R_{c}\right)$, constant of channel maintenance $(C)$ and length of overland flow $\left(L_{g}\right)$ were estimated. Basin relief $(H)$, relief ratio $\left(R_{r}\right)$, channel gradient $\left(C_{g}\right)$ and ruggedness number $\left(R_{n}\right)$ were the relief aspects of the basin which were calculated under morphometric analysis. Mean bifurcation ratio of the watershed has been calculated to be 3.84 which indicates slightly dissected drainage basin. Low drainage density of $2.18 \mathrm{~km} / \mathrm{km}^{2}$ well explains high infiltration in soil and less runoff due to dense forest cover. Form factor ratio and elongation ratio were 0.35 and 0.67 respectively, which favours in lower peaks of longer duration with elongated watershed, which is good for avoiding the floods in downstream. All the above morphometric characteristics calculated suggested that the study area is categorised as $5^{\text {th }}$ order watershed with coarse drainage texture, elongated watershed, the morphometric analysis implies that area has moderate permeable sub-soil and thick vegetative cover that is less prone to erosion.

\section{References}

Bulkley, R. V. 1975. A study of the effects of stream channelization and bank stabilization on warm water sport fish in Iowa: sub-project no. 1. Inventory of major stream alterations in Iowa (No. 76/11). US Fish and Wildlife Service.

Chopra, R., Dhiman, R. D. and Sharma, P. K.2005. Morphometric analysis of subwatersheds in Gurdaspur district, Punjab using remote sensing and GIS techniques. Journal of the Indian Society of Remote Sensing. 33(4): 531.

Horton, R. E. 1932. Drainage-basin characteristics. Eos, transactions American geophysical union. 13(1): 350-361.

Horton, R. E. 1945. Erosional development of streams and their drainage density. Hydrophysical approach to quantitative geomorphology. Geological Society of America Bulletin. 56(1): 275-370.

Jasani, Y. K. and Mansuriya, V. 2011. Geomorphological studies of Meghal river basin using Remote Sensing and GIS. B.Tech. (Agril. Engg.). Thesis (Unpublished). CAET, JAU, Junagadh: 6-13. 
Miller, V. C. 1953. Quantitative geomorphic study of drainage basin characteristics in the Clinch Mountain area, Virginia and Tennessee. Technical report (Columbia University, Department of Geology); no. 3.

Mishra, A., Dubey, D. P. and Tiwari, R. N. 2011. Morphometric analysis of Tons basin, Rewa District, Madhya Pradesh, based on watershed approach. Earth Science India. 4(3): 171-180.

Nag, S. K. 1998. Morphometric analysis using remote sensing techniques in the Chaka sub-basin, Purulia district, West Bengal. Journal of the Indian society of remote sensing. 26(1-2): 69-76.

Saeedrashed, Y. and Guven, A. 2013. Estimation of geomorphological parameters of Lower Zab River-Basin by using GIS-based remotely sensed image. Water Resources Management. 27(1): 209-219.

Schumn, S. A. 1956. Evolution of drainage systems and slopes in badlands at Perth Amboy, New Jersey. Geological Society of America, 67(5): 597-646.

Sethupathi, A. S., Narasimhan, L. C., Vasanthamohan, V. and Mohan, S. P. 2011. Prioritization of miniwatersheds based on Morphometric Analysis using Remote Sensing and GIS techniques in a draught prone Bargur-Mathursub watersheds, Ponnaiyar River basin,
India. International Journal of Geomatics and Geosciences. 2(2): 403.

Singh, V. and Singh, U. C. 2011. Basin Morphometry of Maingra River, district Gwalior, Madhya Pradesh, India. International Journal of Geomatics and Geosciences. 1(4): 891.

Smith, K. G. 1950. Standards for grading texture of erosional topography. American Journal of Science. 248(9): 655-668.

Sreedevi, P. D., Owais, S., Khan, H. H. and Ahmed, S. 2009. Morphometric analysis of a watershed of South India using SRTM data and GIS. Journal of the geological society of India. 73(4): 543-552.

Strahler, A. N. 1964. Quantitative geomorphology of drainage basins and channel networks. In: Handbook of Applied Hydrology. McGraw-Hill, New York. pp. 4-39.

Strahler, A. N. 1968. Quantitative geomorphology. In: Fairbridge, R. W., Ed., The Encyclopedia of Geomorphology, Reinhold Book Corporation, New York.

Strahler, A. N. and Chow, V. T. 1964. Quantitative geomorphology of drainage basins and channel network. In: Handbook of Applied Hydrology. pp. 439-476.

\section{How to cite this article:}

Patel, K.C., N.K. Gontia and Gojiya, K.M. 2019. Morphological Parameters and their Implications in Forest Watershed. Int.J.Curr.Microbiol.App.Sci. 8(04): 2818-2826. doi: https://doi.org/10.20546/ijcmas.2019.804.329 